\title{
AKUSTIK DIBANDINGKAN DENGAN DENSITAS IKAN: KOMBINASI METODE AKTIF DAN PASIF
}

\section{ACOUSTIC VS FISH DENSITY: A COMBINATION OF ACTIVE AND PASSIVE METHOD}

\author{
Zulfathri Randhi ${ }^{1}$, Totok Hestirianoto ${ }^{2}$, Sri Pujiyati ${ }^{2}$ \\ ${ }^{1}$ Program Studi Teknologi Kelautan, Sekolah Pascasarjana \\ ${ }^{2}$ Depertemen Ilmu dan Teknologi Kelautan \\ Fakultas Perikanan dan Ilmu Kelautan, Institut Pertanian Bogor \\ Korespondensi: randhyhamzah@apps.ipb.ac.id
}

\begin{abstract}
Fisheries acoustics has two main division namely active and passive acoustics. Various acoustic studies with active methods have been conducted to assess the relationship between acoustics with fish density, but combination both active and passive methods has never been done to the same fish aggregation. Combining these two methods is expected to deliver an information related to fish density and its trend with both active and passive methods. This study was conducted on tilapia (Oreochromis niloticus) in controlled condition of 50, 100, and 150 fish individuals with total length range of $10-13 \mathrm{~cm}$. Active and passive acoustic data acquisition carried out for 15 minutes on floating net cage of $2 \mathrm{~m} \times 2 \mathrm{~m} \times 1.8 \mathrm{~m}$ in dimension using CruzPro PcFF-80 echosounder $200 \mathrm{kHz}$ (active acoustics) and Dolphin EAR 100 hydrophones (passive acoustics). Active acoustic data is processed using Matlab R2013b to generate value of scattering volume (SV), while passive acoustic data is processed using Wavelab program to obtain the intensity of fish sound in frequency domain, then both are correlated to fish density. The results of SV measurements in fish amounted to 50,100 and 150 individuals respectively were $-45.898 \mathrm{~dB},-45,887 \mathrm{~dB}$ and $-45,888 \mathrm{~dB}$, with the coefficient of determination (R2) reached 0.6583 . There is an average decrease in SV in fish totaling 150 individuals suspected to occur due to shadowing effects, also due to small fish used. The highest and lowest intensity of fish sound of 50 fishes in frequency range $0-22 \mathrm{kHz}$ were $-28.306 \mathrm{~dB}$ and $-64.582 \mathrm{~dB}, 100$ fishes were $-26.0793 \mathrm{~dB}$ and $-64.5296 \mathrm{~dB}, 150$ fishes were $-28.5246 \mathrm{~dB}$ and $-64.5679 \mathrm{~dB}$.
\end{abstract}

Keyword: active acoustic, passive acoustic, sound intensity, scattering volume

\begin{abstract}
ABSTRAK
Akustik perikanan memiliki dua pembagian utama yaitu akustik aktif dan pasif. Berbagai penelitian akustik dengan metode aktif telah dilakukan untuk mengkaji hubungan antara akustik dengan densitas ikan, namun kombinasi metode aktif dengan pasif belum pernah dilakukan sekaligus pada kawanan ikan yang sama. Mengkombinasikan kedua metode ini diharapkan dapat menghasilkan informasi yang berhubungan dengan densitas ikan serta kecenderungannya baik dengan metode aktif maupun pasif. Penelitian ini dilakukan pada kawanan ikan nila (Oreochromis niloticus) dalam kondisi terkontrol berjumlah 50, 100, dan 150 individu ikan dengan kisaran panjang total 10-13cm. Akuisisi data akustik aktif dan pasif dilakukan secara stasioner selama 15 menit pada keramba jaring apung (KJA) ukuran $2 \mathrm{~m} \times 2 \mathrm{~m} \times 1.8 \mathrm{~m}$ menggunakan echosounder CruzPro PcFF-80 frekuensi $200 \mathrm{kHz}$ (akustik aktif) dan hydrophone Dolphin EAR 100 (akustik pasif). Data akustik aktif diolah menggunakan program Matlab R2013b untuk menghasilkan nilai hambur balik volume (scattering volume, SV), sedangkan data akustik pasif diolah menggunakan program Wavelab untuk memperoleh nilai intensitas suara dalam domain frekuensi, selanjutnya keduanya dihubungkan dengan densitas ikan. Hasil pengukuran SV pada ikan berjumlah 50, 100 dan 150 individu secara berturut-turut adalah $-45.898 \mathrm{~dB},-45.887 \mathrm{~dB}$ dan -45.888 $\mathrm{dB}$, dengan koefisien determinasi (R2) mencapai 0.6583. Terdapat penurunan rata-rata SV pada ikan berjumlah 150 individu yang diduga terjadi karena adanya efek shadowing, juga akibat ikan yang digunakan berukuran kecil. Intensitas suara tertinggi dan terendah ikan berjumlah 50 individu pada rentang frekuensi $0-22 \mathrm{kHz}$ berturut-turut sebesar -28.306 dB dan -64.582 dB, pada ikan berjumlah 100 individu, sebesar -26.0793 dB dan -64.5296 dB, pada ikan berjumlah 150 individu sebesar $-28.5246 \mathrm{~dB}$ dan $-64.5679 \mathrm{~dB}$.
\end{abstract}

Kata kunci: akustik aktif, akustik pasif, intensitas suara, scattering volume 


\section{PENDAHULUAN}

Seiring perkembangan teknologi, penelitian untuk memperoleh informasi mengenai sumberdaya ikan meningkat dengan pesat, diantaranya penggunaan suara atau akustik. Metode akustik merupakan salah satu metode yang dapat digunakan untuk memberikan informasi mengenai volume sumberdaya ikan (Simmonds \& MacLennan, 2005). Penggunaan suara untuk mendeteksi sumberdaya ikan yang disebut sebagai akustik perikanan memiliki dua pembagian utama yaitu akustik aktif dan pasif.

Akustik aktif meliputi peralatan seperti echosounder dan sonar yang prinsip kerjanya mentransmisikan atau memancarkan pulsa suara ke badan air dan kemudian dipantulkan oleh obyek seperti ikan, kapal selam maupun dasar perairan (Horne, 2000). Penggunaan echo untuk mendeteksi ikan pada akustik aktif dipelopori oleh Balls pada tahun 1933. Indonesia melakukan penelitian untuk mendeteksi ikan serta densitasnya dengan metode akustik aktif telah dilakukan oleh beberapa peneliti antara lain kebiasaan schooling ikan pelagis (Gerlotto, 1996), densitas akustik sumberdaya ikan pelagis di Selat Sunda (Wijopriono \& Genisa, 2003), eksplorasi sumberdaya ikan demersal (Pujiyati et al. 2007, 2008), target strength untuk identifikasi ikan menggunakan echosounder (Sunardi et al. 2009), karakteristik shoaling ikan pelagis di perairan Selat Bangka (Fauziyah et al. 2010), dan beberapa penelitian lain yang terkait.

Akustik pasif merupakan metode yang menggabungkan ilmu biologi dan akustik untuk mendeteksi atau merekam suara alami yang dihasilkan oleh hewan (Marques et al. 2013) seperti serangga, amfibi, ikan, burung dan mamalia (Juanes, 2002). Terdapat lebih dari 700 spesies ikan dari sekurang-kurangnya 30 famili yang diketahui memproduksi suara dan potensial untuk dideteksi dengan metode akustik pasif (Fish \& Mowbray 1970; Juanes 2002; Kaatz 2002; Johnston \& Phillips 2003; Johnston \& Vives 2003; Rountree et al. 2006). Ikan memproduksi suara dengan maksud tertentu (misal saat berinteraksi, menampakan ciri seksual, echolocation, mempertahankan teritori, kawin) maupun suara insiden sebagai konsekuensi dari aktivitasnya (saat bernafas, makan, bergerak dan tingkah laku lainnya) (Fine et al. 1977; Amorim et al. 2003, 2004; Amorim 2006; Rountree et al.
2006; Luczkovich et al. 2008; Longrie et al. 2008, 2009, 2013; Marques et al. 2013).

Akustik pasif identik dengan penggunaan alat perekam suara sebagai elemen utamanya yaitu hydrophone. Hydrophone merupakan mikrofon bawah air yang mengkonversi tekanan suara menjadi sinyal elektrik sehingga dapat direkam oleh sistem akuisisi data. Aplikasi akustik pasif telah dimanfaatkan selama lebih dari 60 tahun pada biologi dan survei perikanan, diantaranya untuk menentukan penggunaan habitat, menggambarkan dan mengamati area memijah ikan, serta studi tingkah laku ikan (Fish et al. 1952; Fish \& Mowbray 1970; Hawkins 1993; Rountree et al. 2003a, 2003b).

Pada satu dekade terakhir metode pasif telah digunakan untuk menduga densitas ikan meskipun masih dalam tahap pengembangan, yang ditandai dengan masih terbatasnya publikasi internasional pada bidang akustik pasif mengenai densitas dan kelimpahan kawanan ikan. Hal ini disebabkan karena sebelum dapat digunakan untuk mengestimasi kelimpahan, suara ikan berdasarkan tingkah lakunya harus dibedakan dengan baik terlebih dahulu, begitu pula individu ikan yang mengeluarkan suara secara berulang-ulang dengan yang tidak (Rountree et al. 2006; Marques et al. 2013).

Berbagai penelitian akustik dengan metode aktif telah dilakukan untuk mengkaji hubungan antara akustik dengan jumlah ikan, namun kombinasi metode aktif dengan pasif masih sangat jarang atau belum pernah dilakukan sekaligus pada kawanan ikan yang sama. Padahal diketahui bahwa baik nilai hambur balik maupun intesitas suara memiliki proporsionalitas dengan densitas ikan. Mengkombinasikan kedua metode akustik ini diharapkan dapat menghasilkan informasi yang berhubungan dengan densitas ikan serta kecenderungannya baik dengan metode aktif maupun pasif.

\section{METODE PENELITIAN}

Kegiatan penelitian dilakukan pada tanggal 3 September 2015 bertempat di perairan Danau Lido Kabupaten Bogor, Jawa Barat. Sebagai studi pendahuluan, penelitian ini dilakukan pada kawanan ikan dalam kondisi terkontrol dengan beberapa jumlah individu ikan yang ditentukan. Pemeruman sekaligus perekaman suara ikan pada penelitian ini dilakukan pada Keramba Jaring Apung (KJA) ukuran $2 \mathrm{~m} \times 2 \mathrm{~m} \times 1.8 \mathrm{~m}$ 
(jaring terendam sedalam $1.8 \mathrm{~m}$ ). Ikan yang digunakan adalah ikan nila (Oreochromis niloticus) berjumlah 50, 100, dan 150 individu ikan dengan kisaran panjang total $10-13 \mathrm{~cm}$.

Akuisisi data akustik dilakukan secara simultan menggunakan echosounder CruzPro PcFF-80 (untuk akustik aktif) dan hydrophone Dolphin EAR 100 (akustik pasif), yang masing-masing terhubung pada laptop sebagai penampil (display), penyimpan (storage) dan pemroses data (processor). Spesifikasi dan pengaturan peralatan akustik dapat dilihat pada Tabel 1 .

Pemeruman (deteksi secara aktif) dan perekaman suara (deteksi secara pasif) ikan nila dilakukan secara stasioner dan bersamaan selama 15 menit pada masingmasing jumlah ikan. Prosedur penelitian dalam bentuk diagram alir dapat dilihat pada Gambar 1.

Tabel 1. Spesifikasi peralatan akustik yang digunakan

\section{Spesifikasi}

Operation setting

\begin{tabular}{|c|c|}
\hline \multicolumn{2}{|l|}{ Cruzpro PcFF80 } \\
\hline Operating Voltage & $\begin{array}{l}9.5 \text { to } 16.0 \text { VDC, normalnya } 0.05 \text { ampere dan puncaknya } 4.7 \text { ampere } \\
\text { pada saat daya maksimal }\end{array}$ \\
\hline Indikator & $\begin{array}{l}\text { Front panel LED untuk Power ON/Off dan indikator komunikasi } \\
2560 \text { watts puncak kepuncak ( } 320 \text { WMS). }\end{array}$ \\
\hline Output Power & $\begin{array}{l}\text { 24KW pada saat pemrosesan DSP ( } 3200 \text { WRMS) } \\
\text { Kedalaman minimum } 3 \text { feet }(1 \mathrm{~m})\end{array}$ \\
\hline Kemampuan & 1000 feet atau lebih pada $200 \mathrm{kHz}$ \\
\hline kedalaman & $\begin{array}{l}1500 \text { feet atau lebih pada } 50 \mathrm{kHz} \\
0 \text { sampai } 50^{\circ} \mathrm{C}\left(32 \text { sampai } 122^{\circ} \text { Fahrenheit }\right)\end{array}$ \\
\hline $\begin{array}{l}\text { Suhu operasional } \\
\text { Interface Box }\end{array}$ & $\begin{array}{l}100 \times 80 \times 50 \mathrm{~mm}(4 \times 3.2 \times 2 \text { inch). Powder Coated Aluminum Extrusion } \\
\text { RS-232, } 115 \mathrm{KBaud} \text {, serial data and USB } \\
\text { Dual Frequency } 50 / 200 \mathrm{kHz} \text {, Depth/Temperature }\end{array}$ \\
\hline $\begin{array}{l}\text { Interface } \\
\text { Transducer } \\
\text { Signal Processing }\end{array}$ & $\begin{array}{l}\text { Analog Mode \#1: Fixed gain Analog Mode \#2: Time varying gain (TVG) } \\
\text { DSP Mode \#1: Using correlation DSP Mode \#2: Using quadrature } \\
\text { correlation }\end{array}$ \\
\hline \multicolumn{2}{|l|}{ Dolphin EAR 100} \\
\hline $\begin{array}{l}\text { Hidrophone } \\
\text { Kisaran Frekuensi } \\
\text { Power } \\
\text { Arah rekaman }\end{array}$ & $\begin{array}{l}\text { SQ38 nomor seri DE989505 } \\
0-22 \mathrm{kHz} \\
9 \mathrm{~V} \text { Battery } \\
\text { Horizontal - Omni directional }\end{array}$ \\
\hline
\end{tabular}




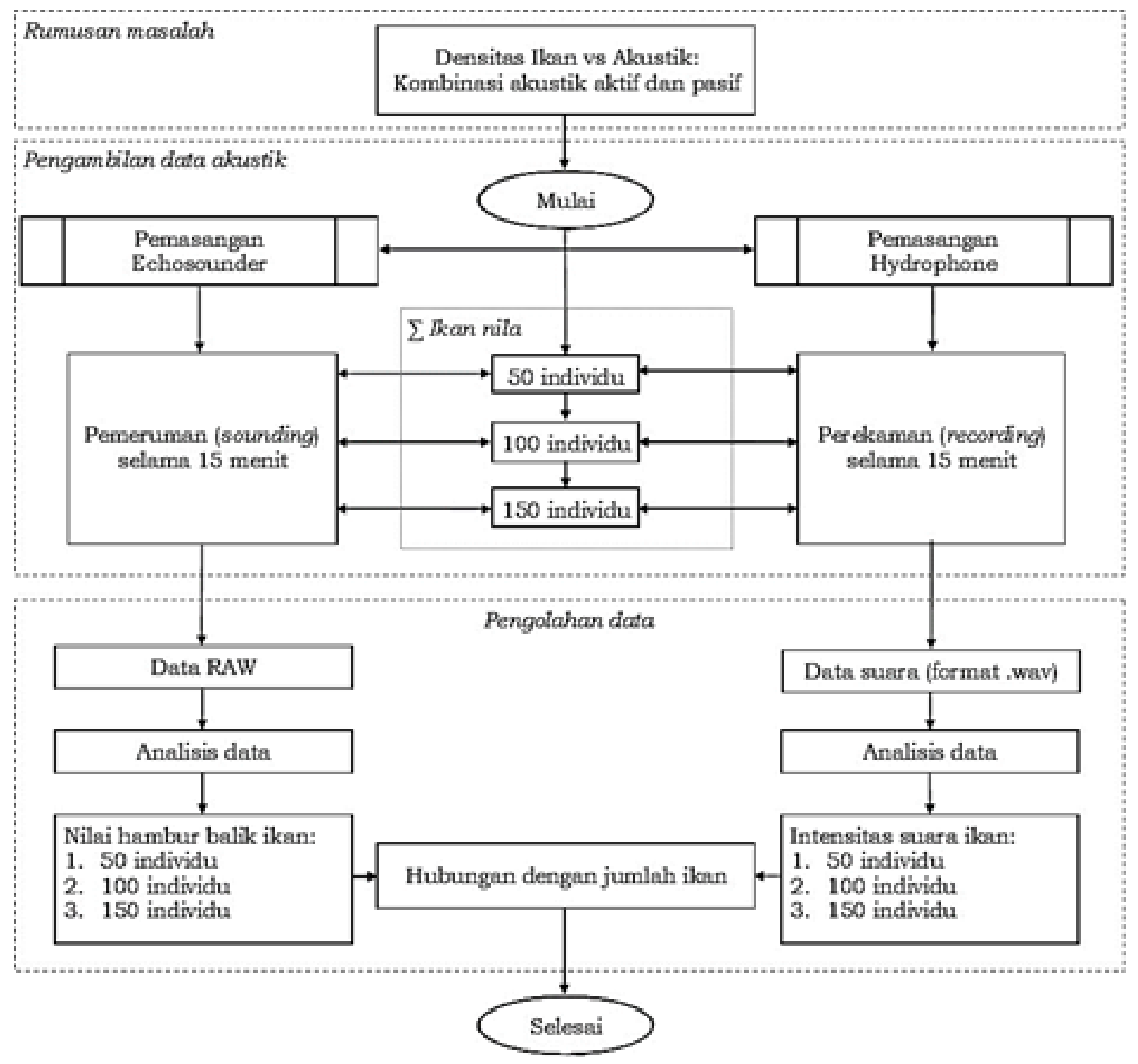

Gambar 1. Diagram alir penelitian

\section{Akustik Aktif}

Frekuensi CruzPro Fish Finder PcFF-80 yang digunakan pada penelitian ini adalah $200 \mathrm{kHz}$, dengan kedalaman pemasangan transducer (depth offset) 0.2 $\mathrm{m}$ di bawah permukaan air. Secara singkat prinsip kerja alat ini adalah transducer (transmitter) memancarkan gelombang suara yang kemudian dipantulkan oleh target, lalu diterima kembali oleh transducer (receiver) (Gambar 2). Sinyal akustik yang diterima oleh transducer dirubah menjadi sinyal elektrik yang selanjutnya diteruskan ke transceiver interface yang akan meneruskan data kedalaman dalam bentuk analog dan digital. Transceiver interface mendapatkan power supply dari accu 12 volt DC yang juga digunakan untuk memberikan arus listrik ke transducer. Selanjutnya data kedalaman yang berasal dari transducer diterima dan direkam ke dalam hardisk PC/laptop dan kemudian ditampilkan di monitor. PC juga dapat melakukan perintah untuk proses akuisisi seperti seperti On/ Off yang disampaikan ke transducer melalui transceiver interface.

Data akustik aktif diolah menggunakan perangkat lunak Microsoft Excel dan Matlab R2013b. Hasil pemeruman berupa raw data diekstrak dan disimpan dalam format .txt lalu diolah menggunakan perangkat lunak Matlab untuk menghasilkan nilai hambur balik volume (scattering volume, $\mathrm{SV}$ ) dalam satuan $\mathrm{dB}$ (decibel). Algoritma yang digunakan untuk mengolah raw data pada program Matlab R2013b mengadaptasi hasil penelitian Ma'mun et al. (2013). 


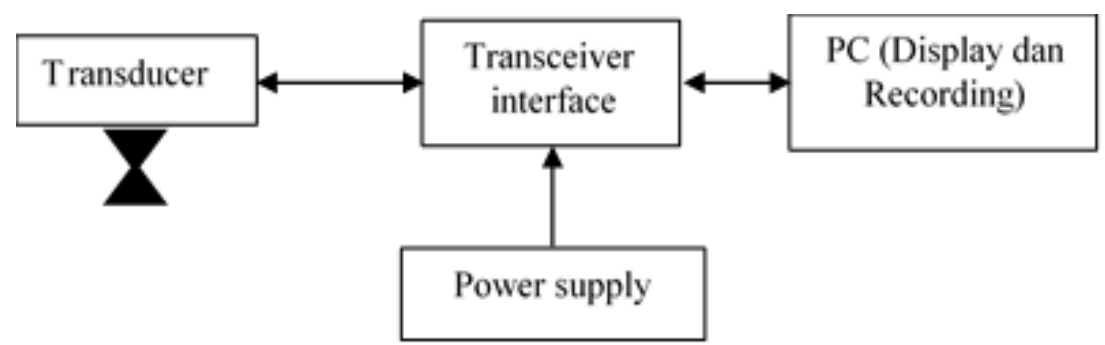

Gambar 2. Prinsip kerja instrumen CruzPro Fish Finder PcFF-80

Nilai hambur balik suara merupakan logaritimik perbandingan antara besarnya intensitas yang dikembalikan oleh target berbanding dengan besarnya intensitas yang dipancarkan oleh peralatan akustik. Besaran yang sering digunakan yaitu desibel (dB) (Lurton, 2002). Sinyal suara yang dipancarkan dari sebuah transducer akan merambat di dalam air dengan kecepatan yang akan dipengaruhi oleh suhu, salinitas, densitas air, perubahan tekanan dan kedalaman perairan. Kedalaman (depth, D) suatu objek (dasar perairan) akan ditentukan oleh waktu tempuh yang diperlukan oleh gelombang suara dari transducer ke dasar perairan dan kembali lagi ke transducer. Kedalaman dan kecepatan suara tersebut dapat dihitung dengan persamaan umum:

$$
\begin{gathered}
D=\frac{C x t}{2} \\
C=1402.388+5.03711 T-0.0580952 T^{2}+ \\
0.3342 \times 10^{-3} T^{3}-0.1478 \times 10^{-5} T^{4}+0.315 \times \\
10^{-8} T^{5}
\end{gathered}
$$

\section{Keterangan:}

$D \quad=$ kedalaman $(\mathrm{m})$

$C \quad=$ kecepatan suara di air tawar $(\mathrm{m} / \mathrm{s})$

(Del Grosso dan Mader, 1972)

$\mathrm{t}=$ waktu $(\mathrm{s})$

$\mathrm{T}=$ suhu air $\left({ }^{\circ} \mathrm{C}\right)$

Pada proses pembentukan, pemancaran dan penerimaan kembali sinyal suara mengalami penyerapan dan penghamburan baik dari suatu medium/ lingkungan (ambient noise) maupun objek yang berada pada kolom air. Gangguan ini juga bisa terjadi pada alat itu sendiri (selfnoise). Gangguan atau noise menyebabkan sinyal suara yang kembali memiliki nilai intensitas yang lemah sehingga dibutuhkan penguatan dengan menggunakan fungsi TVG (Time Varied Gain). Menurut Johanesson \& Mitson (1983) untuk penentuan nilai hambur balik volume (scattering volume) digunakan fungsi TVG untuk multiple target yaitu:

$$
T V G=20 \log r+a r
$$

Keterangan:

$\mathrm{r} \quad=$ near field

$\mathrm{a} \quad=$ koefisien absorpsi dalam unit jarak $(\mathrm{dB} / \mathrm{m})$ (Persamaan 4)

Absorbsi merupakan fungsi dari frekuensi suara, tekanan, suhu, salinitas serta densitas air, sedangkan Near Field merupakan daerah dari depan transducer hingga ke jarak terjauh side lobe yang diukur dari transducer. Absorbsi diperoleh dari persamaan Francois \& Garrison (1982) untuk perairan tawar yaitu:

$$
\begin{gathered}
a=A \times P \times f^{2} \\
A=3.964 \times 10^{-4}-1.146 \times 10^{-5} \mathrm{~T}+1.45 \times 10 \\
{ }^{7} T^{2}-6.5 \times 10^{-10} \mathrm{~T}^{3} \\
P=1-3.83 \times 10^{-5} \mathrm{D}+4.9 \times 10^{-10} \mathrm{D}^{2}
\end{gathered}
$$

Keterangan:

$$
\begin{aligned}
\mathrm{A} & =\text { fungsi absorbsi untuk suhu } \\
\mathrm{P} & =\text { fungsi absorbsi untuk kedalaman } \\
\mathrm{f} & = \\
& \text { frekuensi transducer yang } \\
& \text { digunakan }(\mathrm{kHz})
\end{aligned}
$$

Gelombang suara yang dipancarkan oleh transducer terpusat ke suatu arah tertentu, sehingga intensitas tertinggi dari gelombang tersebut akan terletak pada arah tegak lurus dengan permukaan transducer, yakni yang disebut sumbu akustik (acoustic axis). Sudut bukaan beam dihitung dengan pendekatan:

$$
\begin{gathered}
\theta=10 \log \left(\frac{C \tau \varphi}{2}\right) \\
\varphi=2 \pi b^{2} \\
b^{2}=\frac{1}{2 \pi} \frac{\theta a}{2} \frac{\theta b}{2} \times 10^{-3.16}
\end{gathered}
$$


Keterangan:

$\mathrm{C} \quad=$ Kecepatan suara

$\mathrm{\tau} \quad=$ durasi pulsa (s), (pada echosounder CruzPro bernilai $0.4 \mathrm{~s}$ )

$\psi \quad=$ Sudut reverberasi atau equivalent two-way beam angle

b2 = mean squared beam pattern factor

$\Pi \quad=3.14$

$\theta \mathrm{a}=$ derajat major axis $3 \mathrm{~dB}$ beam angle

$\theta \mathrm{b}=$ derajat minor axis $3 \mathrm{~dB}$ beam angle

Target strength adalah suatu ukuran yang menggambarkan kemampuan objek akustik yang dalam hal ini adalah ikan untuk memantulkan suatu gelombang suara yang datang dan mengenainya. Target strength untuk target tunggal menggunakan fungsi $40 \log \mathrm{r}$, sedangkan untuk multiple target (kawanan) menggunakan fungsi $20 \mathrm{log}$ r (Johanesson \& Mitson, 1983). Pendekatan untuk TS dengan menggabungkan persamaan yaitu:

$$
\begin{gathered}
T S=20 \log (\text { counts })-S L-R S+P S+T V G+\theta \\
\text { counts }=N A 255 \\
P S=A G-A V G
\end{gathered}
$$

Keterangan:

counts = nilai intensitas yang diterima kembali oleh echosounder

NA = Nilai analog akuisisi echosounder (0-255)

SL = Source level, (frekuensi $200 \mathrm{kHz}$ bernilai $222 \mathrm{~dB}$ re $1 \mu \mathrm{Pa}$ pada jarak $1 \mathrm{~m})$

RS = Receiving sensitivity (pada frekuensi $200 \mathrm{kHz}$ bernilai -185)

PS $\quad=$ Power setting (kekuatan listrik yang dinyatakan dalam bentuk logaritmik)

AG = Amplifier Gain (pada echosounder CruzPro bernilai -20.83)

$\mathrm{AVG}=$ Array Voltage Gain $(20 \mathrm{log}$ (jumlah receiver))

Untuk memperoleh nilai scattering volume ikan, maka TVG ditambahkan dengan hasil logaritmik dari luasan area reverberasi. Luasan area reverberasi diperoleh berdasarkan persamaan Desamparados \& Torres (2010), yaitu:

$$
V=10 \log \left(\pi(D \tan \Phi)^{2}\right)
$$

Keterangan:

$$
\begin{aligned}
\mathrm{V} & =\text { Logaritma luasan area reverberasi } \\
\pi & =3.14 \\
\Phi & = \\
& \text { nilai setengah sudut bukaan beam } \\
& (1 / 2 \theta)
\end{aligned}
$$

Nilai scattering volume diperoleh dengan menggabungkan persamaan yang secara matematis menjadi:

$\mathrm{SV}=20 \log ($ counts $)-\mathrm{SL}-\mathrm{RS}+\mathrm{PS}+\mathrm{TVG}+$ $\theta+\mathrm{V}$

Keterangan:

SV = Scattering volume

Counts $=$ Nilai analog akuisisi echosounder CruzPro (0-255)

$\mathrm{SL}=$ Source level (frekuensi $200 \mathrm{kHz}$ bernilai $222 \mathrm{~dB}$ re $1 \mu \mathrm{Pa}$ pada jarak $1 \mathrm{~m})$

RS = Receiving sensitivity (pada frekuensi $200 \mathrm{kHz}$ bernilai -185)

PS = Power Setting (kekuatan listrik yang dinyatakan dalam bentuk logaritmik)

TVG = Time Varied Gain

$\theta=$ Sudut bukaan beam (rad)

$\mathrm{V}=$ Logaritma luasan area reverberasi

Hasil olahan data dari perangkat lunak Matlab kemudian dimasukkan ke dalam perangkat lunak Microsoft Excel. Nilai tersebut kemudian dirata-ratakan dan dibuat dalam bentuk grafik yang menggambarkan nilai SV pada beberapa densitas ikan yang diberikan. Hubungan jumlah ikan dengan SV diperoleh dari nilai regresi linear sederhana antara pertambahan jumlah ikan dengan rata-rata SV.

\section{Akustik Pasif}

Perekaman suara yang diproduksi kawanan ikan dilakukan dengan cara menyambungkan hydrophone ke komputer melalui sound card lalu sensornya dinyalakan dan dicelup ke kolom air sedalam $0.4 \mathrm{~m}$ untuk kemudian melakukan perekaman (Gambar 3).

Data akustik pasif yang direkam memiliki tipe data wav dengan sampling rate $44100 \mathrm{~Hz}$. Data suara ditransformasi secara Fourier (Fast Fourier Transform, FFT) dan diperhalus (smoothing) menggunakan Hamming Window Function pada program Wavelab 6. FFT merupakan algoritma untuk mentransformasi data dari domain waktu ke domain frekuensi, artinya proses perekaman suara disimpan dalam bentuk digital berupa gelombang spektrum suara yang berbasis frekuensi sehingga lebih mudah menganalisis spektrum frekuensi suara yang telah direkam. Secara matematis, persamaan FFT dijabarkan oleh Tan (2008) dalam Persamaan. 


$$
X(m)=\sum_{n=0}^{N-1} x(n) e^{-j\left(\frac{2 \pi}{N}\right) m n}
$$

Keterangan:

$\mathrm{n} \quad=$ indeks sinyal dalam domain waktu $=0,1, \ldots, \mathrm{N}-1$,

$\mathrm{m} \quad=$ indeks sinyal dalam domain frekuensi $=0,1, \ldots, \mathrm{N}-1$,

$\mathrm{e}^{-\mathrm{j}(2 \pi / \mathrm{N}) \mathrm{mn}}=$ konstanta dari nilai sebuah sinyal

Window function atau fungsi jendela merupakan fungsi matematis yang menjadikan nilai nol beberapa interval yang tidak dipilih/diinginkan untuk dianalisis. Persamaan untuk Hamming Window oleh Poularikas (1999) yaitu:

$W_{\text {ham }}(n)=0.54 \pm 0.46 \cos \left(\frac{n \pi}{N} ;\right.$ dengan $\left.-N \leq n \leq N\right)$

Keterangan:

$\mathrm{N} \quad=$ jumlah sampel
Data FFT kemudian diekspor ke dalam bentuk ASCII agar diperoleh nilai energinya (voltase) berdasarkan frekuensi. Untuk menghasilkan nilai intensitas suara dalam decibel $(\mathrm{dB})$, voltase dilogaritmakan dengan persamaan berikut:

$$
I=10 \times \log V
$$

Keterangan:

$\mathrm{I} \quad=$ intensitas suara (decibel, $\mathrm{dB}$ )

$\mathrm{V}=$ energi $($ Volt $)$

Nilai intensitas suara pada masingmasing jumlah ikan dibuat dalam bentuk grafik berdasarkan frekuensinya di program Microsoft Excel. Frekuensi tersebut dikelompokkan menjadi 22 kelas dengan lebar frekuensi $1000 \mathrm{~Hz}$. Hubungan antara jumlah ikan dengan intensitas suaranya diperoleh dari nilai koefisien determinasi (R2) antara pertambahan jumlah ikan dengan peningkatan intensitas suaranya.

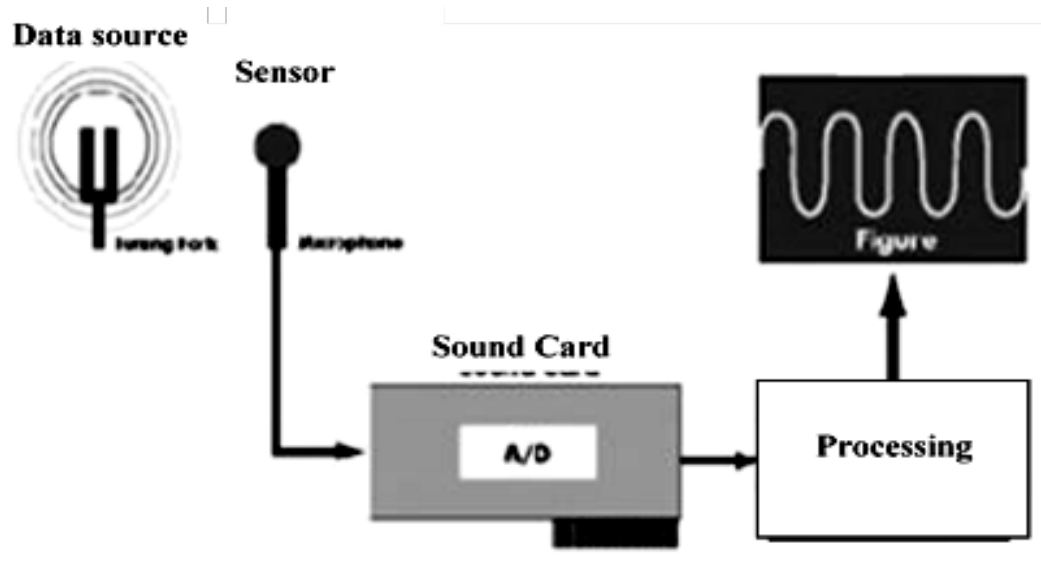

Gambar 3. Prinsip kerja hydrophone

\section{HASIL DAN PEMBAHASAN}

Ikan nila banyak dijadikan sebagai obyek penelitian baik dari segi ekologi, budidaya, serta akustik yang berhubungan dengan tingkah laku. Diketahui pula bahwa ikan nila merupakan peliharaan yang populer di kolam-kolam budidaya air tawar khususnya di Indonesia karena memiliki kemampuan adaptasi yang bagus, pertumbuhan yang cepat serta tahan terhadap serangan penyakit (Kordik, 2010).

\section{Hubungan jumlah ikan dengan scattering volume}

Hasil pengukuran SV pada ikan nila menunjukkan hubungan yang cenderung linear dengan pertambahan jumlah ikan, dengan koefisien determinasi (R2) mencapai 0.6583. Rata-rata SV pada ikan berjumlah 50, 100 dan 150 individu dan standar deviasinya secara berturut-turut adalah $-45.898 \mathrm{~dB}( \pm 0.033),-45.887 \mathrm{~dB}$ $( \pm 0.055)$ dan $-45.888 \mathrm{~dB}( \pm 0.06)$. Grafik yang menunjukkan hubungan antara nilai hambur balik volume ikan nila pada setiap jumlah ikan disajikan pada Gambar 4.

Dalam studi akustik perikanan dengan metode akustik aktif khususnya pada kawanan ikan dalam kondisi terkontrol dikenal adanya prinsip linearitas. Secara sederhana, prinsip linearitas ini diartikan bahwa echo atau pantulan suara yang dihasilkan akan selalu linear dengan penambahan jumlah ikan yang dideteksi 
(Simmonds \& MacLennan, 2005). Namun menurutRøttingen(1976)yangbereksperimen dengan ikan dalam kurungan, hubungan linearitas ini akan proporsional sampai pada batas tertentu saja, dan setelahnya akan menjadi tidak linear. Foote (1978) kemudian menambahkan bahwa hal ini dapat terjadi karena adanya efek shadowing.

Efek shadowing dapat diartikan bahwa pada ikan dengan kepadatan tinggi sinyal akustik yang mengenai kawanan tersebut seluruhnya dipantulkan sebelum memasuki keseluruhan kawanan, sehingga hanya ikan pada lapisan terluar yang memproduksi echo. Hal inilah yang menyebabkan bias pada estimasi densitas ikan dengan akustik. Selanjutnya Foote (1983) juga menjelaskan bahwa shadowing dapat diartikan sebagai atenuasi (penyerapan) energi akustik dari ikan yang lebih dekat pada transducer sehingga ikan yang lebih jauh jaraknya memberi kontribusi yang lebih kecil terhadap sinyal akustik yang diterima.

Berdasarkan data yang diperoleh, terdapat penurunan nilai SV pada ikan berjumlah 150 individu, diduga hal ini dapat terjadi karena adanya efek shadowing. Selain disebabkan kepadatan kawanan ikan yang tinggi, efek shadowing juga dapat dipengaruhi oleh ukuran ikan. Røttingen (1976) membandingkan echo yang dipantulkan ikan yang berukuran kecil (panjang $12 \mathrm{~cm}$ ) dan besar (panjang $35 \mathrm{~cm}$ ) dan menemukan bahwa shadowing dapat terjadi pada kepadatan ikan yang tinggi dengan ukuran yang lebih kecil. Ukuran ikan yang digunakan pada penelitian ini masuk dalam kategori ikan kecil yang panjangnya berkisar 10-13 cm, sehingga penurunan nilai SV pada ikan berjumlah 150 individu dapat disebabkan oleh efek shadowing.

\section{Hubungan jumlah ikan dengan intensitas suara}

Pada penelitian ini suara ikan yang dianalisis tidak dibedakan terlebih dahulu menurut karakteristiknya. Semua jenis suara yang dapat dideteksi oleh hydrophone dianalisis untuk menghasilkan informasi total intensitas suara yang dihasilkan oleh masing-masing jumlah ikan. Grafik intensitas suara dan frekuensi tersaji pada Gambar 5.

Secara keseluruhan, intensitas suara tertinggi pada kawanan ikan berjumlah 50 individu adalah sebesar $-28.306 \mathrm{~dB}$, sedangkan intensitas terendahnya -64.582 dB. Pada ikan berjumlah 100 individu, intensitas suara tertinggi adalah -26.0793 $\mathrm{dB}$ dan intensitas suara terendahnya $-64.5296 \mathrm{~dB}$. Pada ikan berjumlah 150 individu, intensitas suara tertinggi yang diperoleh adalah $-28.5246 \mathrm{~dB}$ sedangkan terendahnya -64.5679 dB.

Untuk memperoleh hubungan jumlah ikan dengan intensitas suaranya maka nilai intensitas perlu dirata-ratakan berdasarkan pengelasan frekuensi. Ratarata intensitas suara ikan nila berdasarkan kelas frekuensinya dapat dilihat pada Tabel 2 .

Berdasarkan pada Tabel 2, terdapat tiga kelas frekuensi yang memiliki nilai intensitas suara yang cenderung linear dengan pertambahan jumlah ikannya (tercetak tebal). Pada kelas frekuensi 1001$2000 \mathrm{~Hz}$, intensitas suara ikan 50, 100 dan 150 individu secara berturut-turut adalah $-36.5911 \mathrm{~dB},-34.1864 \mathrm{~dB}$ dan -34.5297 $\mathrm{dB}$ dengan nilai koefisien determinasi (R2) yang menunjukkan hubungan linear sebesar 0.628. Pada kelas frekuensi 7001$8000 \mathrm{~Hz}$, diperoleh intensitas suara untuk 50 individu ikan sebesar $-45.5428 \mathrm{~dB}, 100$ individu sebesar $-40.6067 \mathrm{~dB}$ dan 150 individu sebesar $-41.2453 \mathrm{~dB}$, dengan nilai R2 sebesar 0.6406. Pada kelas frekuensi $8001-9000 \mathrm{~Hz}$, intensitas suara 50 individu ikan sebesar $-53.6276 \mathrm{~dB}, 100$ individu ikan sebesar -48.7421 dB dan 150 individu sebesar -49.3761 dB, dengan nilai R2 sebesar 0.6403. Grafik yang menunjukan hubungan linear antara jumlah ikan dengan intensitas suaranya pada kelas frekuensi $1001-2000 \mathrm{~Hz}, 7001-8000 \mathrm{~Hz}, 8001-9000$ $\mathrm{Hz}$ dapat dilihat pada Gambar 6. 


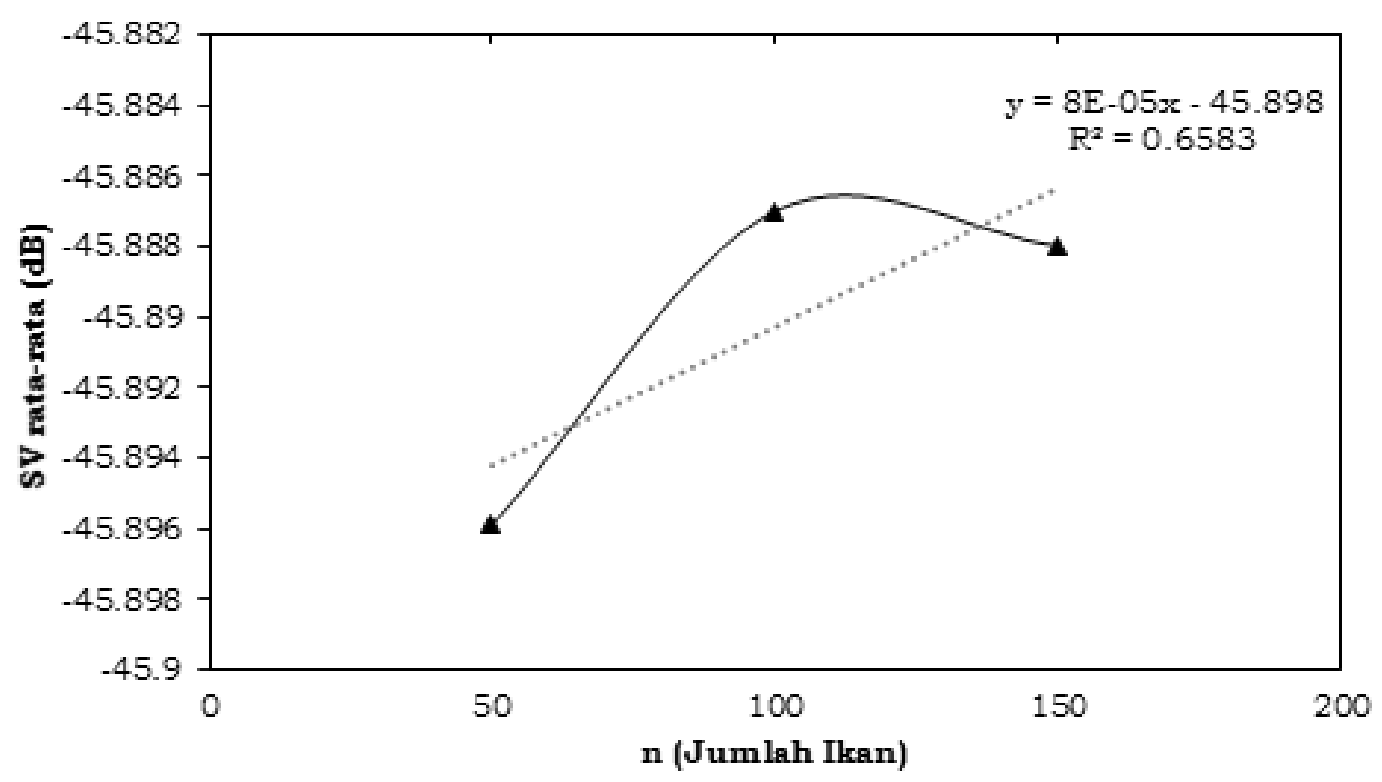

Gambar 4. Hubungan jumlah ikan dengan nilai rata-rata scattering volume

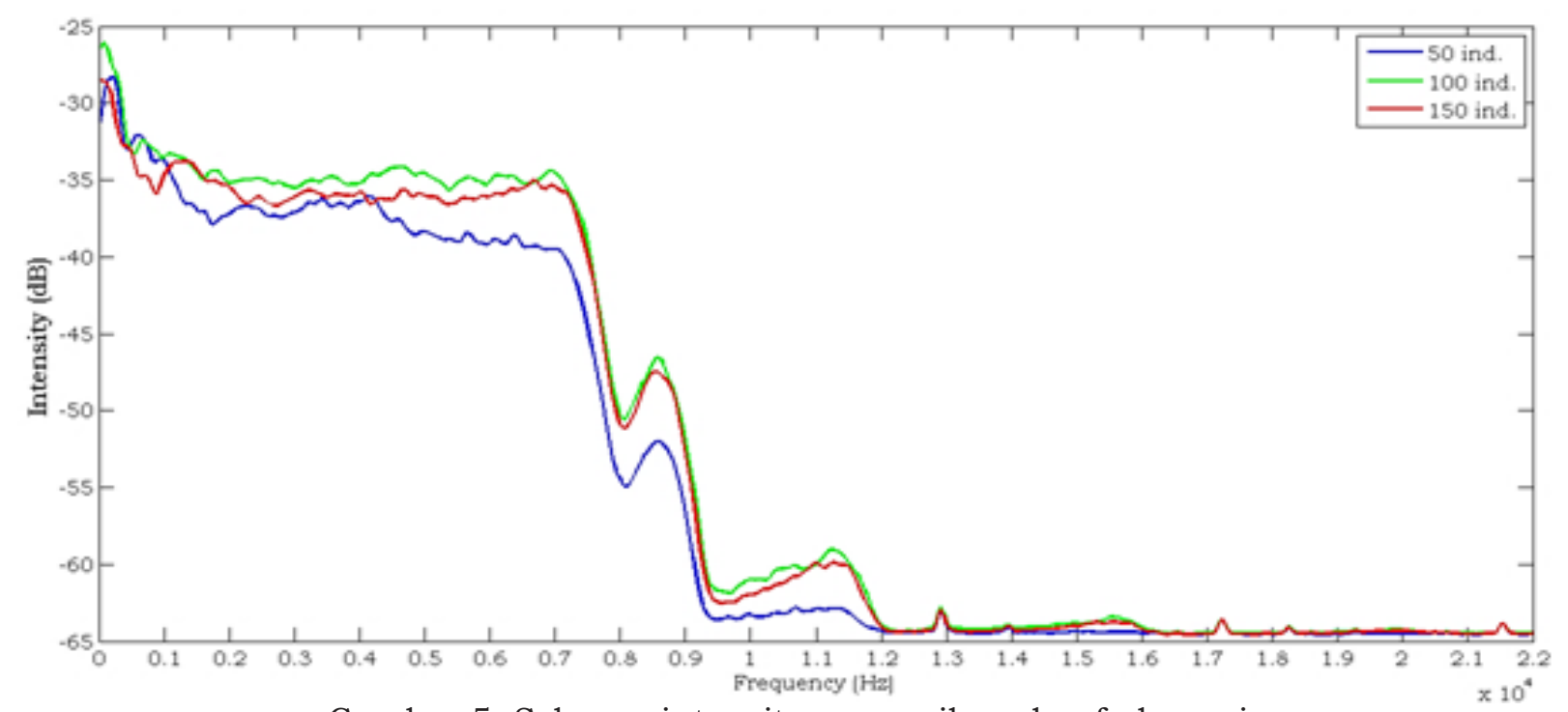

Gambar 5. Sebaran intensitas suara ikan dan frekuensinya

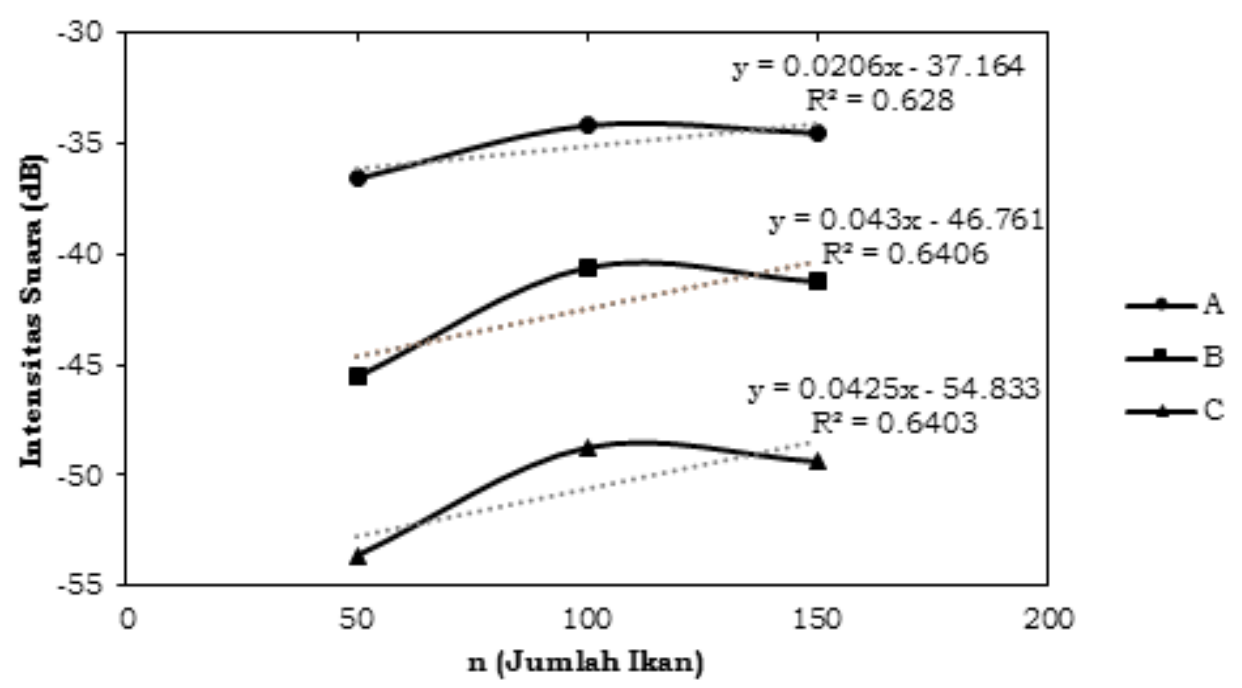

Gambar 6. Hubungan jumlah ikan dengan nilai intensitas suara (dB). Kelas frekuensi (Hz): (A) 1001-2000, (B) 7001-8000, (C) 8001-9000 
Tabel 2. Rata-rata intensitas suara ikan berdasarkan kelas frekuensi

\begin{tabular}{|c|c|c|c|}
\hline \multirow{2}{*}{$\begin{array}{c}\text { Kelas } \\
\text { Frekuensi (Hz) }\end{array}$} & \multicolumn{3}{|c|}{ Rata-rata Intensitas Suara (dB) } \\
\hline & 50 ind. & 100 ind. & 150 ind. \\
\hline $0-1000$ & -31.7126 & -30.8126 & -32.7944 \\
\hline $1001-2000$ & -36.5911 & -34.1864 & -34.5297 \\
\hline 2001-3000 & -37.0806 & -35.1351 & -36.3261 \\
\hline $3001-4000$ & -36.6283 & -35.1217 & -35.9335 \\
\hline $4001-5000$ & -37.4132 & -34.5369 & -36.0961 \\
\hline $5001-6000$ & -38.8518 & -35.1215 & -36.372 \\
\hline $6001-7000$ & -39.186 & -34.8649 & -35.5659 \\
\hline $7001-8000$ & -45.5418 & -40.6067 & -41.2453 \\
\hline $8001-9000$ & -53.6276 & -48.7421 & -49.3761 \\
\hline $9001-10000$ & -62.6549 & -60.0263 & -60.8223 \\
\hline $10001-11000$ & -63.1605 & -60.4728 & -61.099 \\
\hline $11001-12000$ & -63.4078 & -60.5888 & -61.1022 \\
\hline $12001-13000$ & -64.238 & -64.0891 & -64.1766 \\
\hline $13001-14000$ & -64.3947 & -64.1323 & -64.2863 \\
\hline $14001-15000$ & -64.4494 & -64.0018 & -64.1946 \\
\hline $15001-16000$ & -64.4139 & -63.71 & -63.8768 \\
\hline $16001-17000$ & -64.518 & -64.4277 & -64.4917 \\
\hline $17001-18000$ & -64.4212 & -64.3603 & -64.4164 \\
\hline $18001-19000$ & -64.5022 & -64.4052 & -64.4501 \\
\hline $19001-20000$ & -64.5058 & -64.3156 & -64.3685 \\
\hline $20001-21000$ & -64.5083 & -64.4142 & -64.433 \\
\hline $21001-22000$ & -64.459 & -64.406 & -64.4348 \\
\hline
\end{tabular}

\section{KESIMPULAN}

Metode akustik aktif dan pasif memiliki proporsionalitas dengan densitas ikan, sehingga kedua metode tersebut dapat digunakan untuk mengetahui densitas ikan. Semakin banyak jumlah individu maka semakin tinggi nilai scattering volume dan intensitas suara yang dihasilkan.

\section{DAFTAR PUSTAKA}

Amorim MCP, Fonseca PJ, Almada VC. 2003. Sound Production during Courtship and Spawning of Oreochromis mossambicus: male-female and malemale interactions. Journal of Fish Biology. 62:658-672.

Amorim MCP, Stratoudakis Y, Hawkins AD. 2004. Sound Production during Competitive Feeding in the Grey Gurnard. J Fish Biol. 65:182-194.

Amorim MCP. 2006. Diversity of Sound Production in Fish. Di dalam: Ladich F, Collin SP, Moller P, Kapoor BG, editor. Communication in Fishes Vol 1. Science Publishers, Enfield. 77-104.

Del Grosso VA, Mader CW. 1972. Speed of sound in pure water. J. Acoustics
Society of America. 52:1442-6.

Desamparados M, Torres M. 2010. Theoretical and Experimental Studies of Seafloor Backscatter. Centre for Marine Science and Technology, Curtin University of Technology, Perth, Australia.

Fauziyah, Hartoni, Agussalim A. 2010. Karakteristik Shoaling Ikan Pelagis Menggunakan Data Akustik Split Beam di Perairan Selat Bangka pada Musim Timur. J Ilmu Kelautan. 15(1):17-22. ISSN 0853-7291.

Fine ML, Winn HE, Olla BL. 1977. Communication in fishes. In: How Animals Communicate (ed. T.A. Sebeok):472-518. Bloomington: Indiana University Press.

Fish MP, Kelsey ASJ, Mowbray WH. 1952. Studies on the Production of Underwater Sound by North Atlantic Coastal Fishes. J Marine Resources. 11:180-193.

Fish MP, Mowbray WH. 1970. Sounds of Western North Atlantic Fishes. Baltimore (Maryland): John Hopkins Press.

Foote KG. 1978. Analyses of empirical observations on the scattering of sound by encaged aggregations of fish. 
FiskDir Skr Ser Havunders. 16:55-422.

Foote KG. 1983. Linearity of Fisheries Acoustics, with addition theorems. $J$ Acoustics Society of America. 73:401932

Francois RE, Garrison GR. 1982. Sound absorption based on ocean measurements. Part II: Boric acid contributions and equation for total absorption. $J$ Acoustics Society of America. 72:1879-90.

Gerlotto F. 1996. Gregariousness and School Behaviour of Pelagic Fish: Impact of the Acoustics Evaluation and Fisheries. Proceeding of Acoustics Seminar Akustikan 2:233-252. ISBN No. 9798186-64-8.

Hawkins AD. 1993. Underwater Sound and Fish Behaviour. In: Pitcher TJ (ed) Behaviour of Teleost Fishes 2nd edn:129-169. London: Chapman \& Hall

Horne JK. 2000. Acoustic Approaches to Remote Species Identification: a review. Fisheries Oceanography. 9, 356-71.

Johanesson KA, Mitson RB. 1983. Fisheries acoustics: a practical manual for biomass estimation. FAO Fisheries Technical Paper 240.

Johnston CE, Phillips CT. 2003. Sound Production in Sturgeon, Scaphirhynchus albus and $S$. Platorynchus (Acipenseridae). Environmental Biology of Fishes. 68:59-64.

Johnston CE, Vives SP. 2003. Sound Production in Codoma Ornata (Girard) (Cyprinidae). Environmental Biology of Fishes. 68:81-85.

Juanes F. 2002. Listening to Fish: an International Workshop on the Application of Passive Acoustics in Fisheries. Reviews in Fish Biology and Fisheries. 12:105-106.

Kaatz IM. 2002. Multiple Sound Producing Mechanism in Teleost Fishes and Hypotheses Regarding Their Behavioural Significance. Bioacoustics. 12:230-233.

Kordik K. 2010. Budidaya Ikan Nila di Kolam Terpal. Yogyakarta (ID): Lily Publisher.

Longrie N, Fine ML, Parmentier E. 2008. Innate Sound Production in the Cichlid Oreochromis niloticus. $J$ Zoology. 275:413-417. doi:10.1111/j.14697998.2008.00457.x.

Longrie N, Poncin P, Denoël M, Genotte V, Delcourt J, Parmentier E. 2013. Behaviours Associated with Acoustic
Communication in Nile Tilapia (Oreochromis niloticus). PLoS ONE. 8(4): e61467. doi:10.1371/ journal. pone. 0061467 .

Longrie N, Van Wassenbergh S, Vandewalle P, Mauguit Q, Parmentier E. 2009. Potential Mechanism of Sound Production in Oreochromis niloticus (Cichlidae). J Exp Biol. 212:3395-3402. doi:10.1242/jeb.032946.

Luczkovich JJ, Mann DA, Rountree RA. 2008. Passive Acoustics as a Tool in Fisheries Science. Transactions of the American Fisheries Society. 137:533541.

Lurton X. 2002. An Introduction to Underwater Acoustics: Principles and Applications. Chichester: Praxis Publishing.

Ma'mun A, Manik HM, Hestirianoto T. 2013. Rancang Bangun Algoritma dan Aplikasinya pada Akustik Single Beam untuk Pendeteksian Bawah Air. Jurnal Teknologi Perikanan. 4(2):173-183. ISSNN 2087-4871.

Marques TA, Thomas L, Martin SW, Mellinger DK, Ward JA, Moretti DJ, Harris D, Tyack PL. 2013. Estimating Animal Population Density using Passive Acoustics. Biol Rev. 88(2013):287-309.

Poularikas AD. 1999. Windows: The Handbook of Formulas and Tables for Signal Processing. Boca Raton: CRC Press LLC

Pujiyati S, Suwarso, Pasaribu BP, Jaya I, Manurung D. 2008. Pendekatan Metode Hidroakustik untuk Eksplorasi Sumberdaya Ikan Demersal di Perairan Utara Jawa Tengah. Ichthyos. 7(1):1520.

Pujiyati S, Wijopriono, Mahiswara, Pasaribu BP, Jaya I, Manurung D. 2007. Estimasi Hambur Balik Dasar Perairan dan Sumberdaya Ikan Demersal Menggunakan Metode Hidroakustik. $J$ Lit Perikanan Ind. 13(2):145-155.

Røttingen I. 1976. On the relation between echo intensity and fish density. FiskDir Skr Ser Havunders. 16 (9):14-301.

Rountree RA, Gilmore RG, Goudey CA, Hawkins AD, Luczkovich JJ, Mann DA. 2006. Listening to Fish: Applications of Passive Acoustics to Fisheries Science. Fisheries. 31(9):433-446.

Rountree RA, Goudey C, Hawkins T, Luczkovich J, Mann D. 2003a. Listening to Fish: Passive Acoustic Applications in Marine Fisheries [Internet]. Sea Grant Digital Oceans. Massachusetts Institute of Technology 
Sea Grant College Program. MITSG 0301. Tersedia pada: http://web.mit. edu/seagrant/aqua/cfer/acoustics / PD9x9FINAL.pdf

Rountree RA, Goudey C, Hawkins T. 2003b. Listening to Fish: Proceeding of the International Workshop on the Applications of Passive Acoustic to Fisheries [Internet]. 2002 Apr 8-10; Dedham (MA): MIT Sea Grant Technical Report MITSG 0302. Tersedia pada: http:/ / web.mit.edu/seagrant/aqua/ cfer/acoustics/PAprocBrFINAL.pdf

Simmonds J, MacLennan D. 2005. Fisheries Acoustics: Theory and Practice 2nd
Edition. Blackwell Science Ltd.

Sunardi, Din J, Yudhana A, Hassan RBR. 2009. Target Strength for Fish Identification Using Echosounder. Applied Physics Research. 1(2):92-101.

Tan L. 2008. Digital Signal Processing: Fundamentals and Applications. USA: Academic Press, Elsevier.

Wijopriono dan Genisa AS. 2003. Densitas Akustik Sumberdaya Ikan Pelagis di Selat Sunda. Di dalam Ruyitno, Pramudji, Supangat I, Sunarto, editor. Pesisir dan Pantai Indonesia IX. Pusat Penelitian Oseanografi LIPI, Jakarta. Hlm 69-73. 